\title{
RÉPLICA AO ARTIGO DE JURANDYR L. ROSS, “O CONTEXTO TECTÔNICO E A MORFOGÊNESE DA PROVÍNCIA SERRANA DE MATO GROSSO", REV. IG 12(1/2) 21-37
}

Setembrino PETRI

Vicente José FƯLFARO

O Dr. Ross apresenta interessante trabalho sobre a Província Serrana, divisor de água dos rios Cuiabá e Paraguai, Arinos e Teles Pires. É natural que como geomorfólogo enfatize as interpretações de superfícies erosivas.

A discordância, relativa a nossa interpretação de que a Província Serrana poderia ter sido área-fonte tanto da Formação Parecis como Bauru, não se encontra, a nosso ver, suficientemente embasada. O próprio autor reconhece que é discutível a validade de relação direta entre níveis morfológicos e ciclos de erosão em áreas de exposições descontínuas. Este autor escreve, erroneamente, que consideramos lentes de conglomerados como Cenozóicos. Existem, na Formação Parecis, lentes de conglomerados como já afirmamos (PETRI \& FULFARO, 1981, p. 278). O que consideramos Cenozóicos são cascalheiras formando fanglomerados (PETRI \& FULFARO, op. cit., p. 279).

Não nos convence a argumentação de que a Província Serrana não foi divisor da bacia Parecis e Bauru, pois não foram consideradas as paleocorrentes, dirigidas para o quadrante $N$ durante o Cretáceo e para o quadrante $S$ durante o Cenozóico, na região em pauta, mostrando completa reestruturação neste intervalo de tempo.
Reconhece o autor que " não se pode descartar totalmente a Província Serrana como parte significativa da área-fonte dos sedimentos Parecis, visto que ocorrem seixos de arenitos semelhantes aos conhecidos na área serrana adjacente" (o grifo é nosso).

WESKA (1987) e WESKA et al. (1988) identificaram, no Cretáceo da região de Chapada dos Guimarães, três facies que vão adquirindo características cada vez mais distais para NW. ARMANDO MÁRCIO COIMBRA (comunicação verbal) - que participou da Comissão Examinadora de mestrado de WESKA (1987) e que esteve no local de pesquisa de Weska, previamente à defesa da dissertação - notou que, além das facies cada vez mais finas para NW, as paleocorrentes também se dirigem para o mesmo rumo. Chamou a atenção, durante a defesa, para o fato de que se tratava de uma bacia independente e que, portanto, o nome Bauru era impróprio para os sedimentos cretáceos desta bacia. SIQUEIRA (1988) considerou a bacia Parecis mais próxima da de Solimões do que de outras. Existe a possibilidade de que a bacia cretácea de Parecis esteve em continuidade com a cretácea da Chapada dos Guimarães.

\section{REFERÊNCIAS BIBLIOGRÁFICAS}

PETRI, S. \& FULFARO, V. J. 1981. Geologia da Chapada dos Parecis, Mato Grosso, Brasil - Rev. Bras. Geoc. 11(4): 274-283.

SIQUEIRA, L. P. 1989. Bacia de Parecis - Bol. Geociências. Petrobrás, 3 (1/2): 3-16.

WESKA, R. K. 1987. Placers diamantíferos da região de Água Fria, Chapada dos Guimarães, MT - Dissertação Mestrado (Inédita).
WESKA, R. K.; DANI, J. C. M.; DARDENNE, M. A. \& PERUI, A. L. 1988. Contribuição à estratigrafia do Grupo Bauru na região da Chapada dos Guimarães, MT. Anais XXXV Congr. Bras. Geol. 2:905-916. 